Trakya Eğitim Dergisi

Cilt 10, Sayı 1

Ocak 2020, 276-284

Gelis Tarihi: 22.05.2019

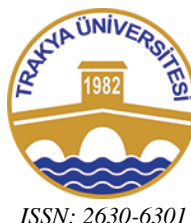

ISSN: 2630-6301
Trakya Journal of Education

Volume 10, Issue 1

January 2020, 276-284

\title{
A Case Study: Literacy Experiences of Struggling Readers with Interactive Digital Books
}

\author{
Vaka Çalışması: Okuma Güçlüğü Çeken Okurların Interaktif Dijital Kitap ile Okuma- \\ Yazma Tecrübeleri
}

\section{Emine DEMiRÖZ1}

\begin{abstract}
Öz: Okuma testlerinde, standart beklentilerin bir veya daha fazla seviye altında puan alan öğrenciler okuma güçlüğü çeken öğrenciler olarak tanımlanır. Okuma güçlüğü çeken öğrenciler, okuma-yazma faaliyetlerini destekleyen etkili uygulamalar kullanıldığında okuma testlerinde bașarılı olmaya meyilliler. Son zamanlarda, teknoloji kullanımı okuma güçlüğü çeken öğrencilere modern okuma eğitimi olarak verilen en popüler uygulamalardan biridir. Bu çalışmada, altı 3. sınıf okuma güçlüğü çeken öğrencinin interaktif dijital kitaplar ile deneyimleri incelenmiştir. Veri kaynakları olarak yarı-yapılandırılmış görüşmeler, dökümanlar ve alan notları kullanılmıştır. Bu çalışma, her okuma güçlüğü çeken öğrencinin ihtiyacına yönelik özel bir okuma-yazma müfredatına ihtiyaç duyulduğunu ortaya çıkarmıştır. Çalışmanın sonucuna göre, interaktif dijital kitaplar, yetişkin yönlendirmesinin ve kullanılan kitabın kalitesine bağlı olarak, öğrenciler için teşvik edici veya cesaret kırıcı olabilmektedir.
\end{abstract}

Anahtar sözcükler: Okuma güçlüğü çeken okur, teknoloji, interaktiflik, interaktif dijital kitaplar.

\begin{abstract}
Students who score one or more grade levels below the standard expectations in reading tests are defined as struggling readers. Struggling readers tend to succeed in reading assessments when effective interventions are integrated to support their literacy practices. Recently, technology use has been one of the most popular interventions in contemporary reading instruction for struggling readers. In this study, experiences of six 3rd grade struggling readers within tutoring sessions to explore their experiences with interactive digital boks are examined. Data collection sources included semistructured interviews, document collection, and field notes. This study revealed that every struggling reader needs a special literacy curriculum with strategies that are unique to their needs. The findings also suggested that interactive digital books might be either encouraging or discouraging for students depending on the quality of digital books and adult guidance.
\end{abstract}

Keywords: Struggling reader, technology, interactivity, interactive digital books.

Cite this article as:

Demiröz, E. (2020). A case study: Literacy experiences of struggling readers with interactive digital books. Trakya Ë̆itim Dergisi, 10(1), $276-284$

\section{UZUN ÖZET}

Standart testerde seviyesinden bir veya daha az seviyede çıkan kişiler okuma-yazma güçlüğü çeken okuyucular olarak nitelendirilir. Bu bireylerin güçlük çekmesinin değişik sebepleri olabilir. Günümüz teknolojilerinin yardımıyla, eğitim teknolojilerinden faydalanarak, bu bireylerin okumayazma sorunları azaltılabilir ve hatta ortadan kaldırılabilir. Bu çalışmada, interaktif dijital kitaplar kullanarak, Orta Amerika'da bir ilkokulda altı 3. sinif öğrencisinin okuma-yazma tecrübeleri incelenmiştir. Bu çalışmada nitel veri analizi kullanılmıştır. Araştırma, okuma-yazma güçlügü çeken okuyucuların, interaktif dijital kitap kullanımında, okuduklarını anlama ve motivasyonunu nasıl etkilediğini ve okuyucuların bu tecrübeleri nasıl tanımladığını gözler önüne sermiștir. Veri, iki adet yarı-yapılandırılmış görüşme, doküman ve alan notları aracılığı ile toplanmıştır. Her bir katılımcı ile iki ay boyunca her hafta iki adet yarım saatlik oturumlar halinde birebir çalışılmıştır. Toplamda, altı katılımcı ile 16 bireysel yarım saatlik oturum yapılmıştır. Katılımcıların seviyelerine uygun interaktif kitaplar kullanılmıștır. Veri analizinde tema analizi yapılmıștır. İlk aşamada, alan notları, görüşme transkriptleri ve her katılımcının dokümaları ham veri olarak toplanmıştır. Genel anlama için tüm veriler

\footnotetext{
${ }^{1}$ Öğr. Gör. Dr. Trakya Üniversitesi, e-posta: eminedemiroz1@trakya.edu.tr, ORCID: 0000-0002-3209-4908
} 
okunduktan sonra, araştırma sorularıyla uyuşan betimleyici kodlar verilmiştir. Tüm ham veriler el ile analiz edildikten sonra, betimleyici kodlar her katılımcı için excel dosyasına girilmiştir. Betimleyici kodları analiz ettikten sonra, hepsi her katılımcı için açıklayıcı kodlar altında gruplandırılmıştır. Son olarak da, açıklayıcı kodlar, daha geniş temalar altında her katılımeı için gruplandırılmıştır. Bu gruplandırmada üç ana tema ortaya çıkmıştır: 'bariyer' 'motivasyon' ve 'teknoloji'. Her temanın altında katılımcıların tecrübeleri onlarla alakalı betimleyici kodlarla ilişkilendirilerek sunulmuştur. Çalışmanın sonucuna göre, interaktif dijital kitaplar, yetişkin yönlendirmesinin ve kullanılan kitabın kalitesine bağl1 olarak, öğrenciler için teşvik edici veya cesaret kırıcı olabileceği tespit edilmiştir. Ayrıca okuma-yazma güçlügü çeken öğrencilerin, ihtiyaçlarına uygun bireyselleştirilmiş bir müfredata ihtiyaç duydukları ve birebir veya mini-gruplar halinde çalışıldığında daha faydalı olacağı yönünde tespitler de yapılmıştır.

\section{INTRODUCTION}

The National Center for Education Statistics (NCES) showed that in 1992, 38\% of fourth grade students in the United States scored below the basic level of reading expected for their age (Kena et al., 2014). These data indicated that students scored below partial mastery of fundamental skills in reading. In 2013, the results of NCES showed that the percentage of fourth grade students performing below the basic level of reading expected for their age was 32\%, which is lower than the percentage in 1992 (Kena et al., 2014). Although there seems to be a decrease in the number of fourth grade students who scored below the basic level between the years of 1992 and 2013, it is clear from the same data that there are still many students who continue to fail state and standardized reading tests.

Students who score one or more grade levels below the standard expectations in reading tests are defined as struggling or emergent readers (Guthrie \& Davis, 2003). There are many reasons why these students struggle with reading texts: they might have a disability that makes reading difficult to learn; they might come to school without much literacy experience, or they might have received poor or inadequate reading instruction. Some struggling readers suffer from limited vocabulary, while others cannot summarize the text or synthesize it with other texts (Allington, 2007). Although various interventions have been used to support struggling readers, they continue to have difficulty in state and standardized reading tests. Effective interventions need to be initiated to support struggling readers' literacy practices. Technology use has been one of the most popular interventions in reading instruction for struggling readers (Cheung \& Slavin, 2013). Research has backed up the importance of providing support through using new literacy tools for struggling readers (Anderson-Inman \& Horney, 2007; Boone \& Higgins, 2007; Cheung \& Slavin, 2013; Slavin, Lake, Davis, \& Madden, 2011; Wasik \& Slavin, 1993). Although there is abundant research on the use of educational technology in literacy practices (Cheung \& Slavin, 2013; Falth, Gustafson, Tjus, Heimann, \& Svensson, 2013; Gibson, Cartledge, \& Keyes, 2011; Laverick, 2014), not many of them focus on the use of educational technology in the reading practices of struggling readers.

Recently, digital books have begun to include more features to attract readers. These enhanced features in digital books are called interactive digital books. They provide readers with more interaction with the text. Interactive digital books also support vocabulary learning and comprehension when animations and sound effects are related to the content (Zucker, Moody, \& McKenna, 2009); however, research displayed how one must be careful in using them, especially with children. When such interactive features are irrelevant to the text, they might distract readers and even interfere with their recall of significant details (Dalton, 2014). In an exploratory study with 24 pairs of adults and children (ages 3-5), researchers at the Joan Ganz Cooney Center (Chiong, Ree, Takeuchi, \& Erickson, 2012) explored enhanced e-book use on iPads. The study revealed that children preferred to read an enhanced digital book over a basic digital book, but they remembered fewer details of the content with enhanced digital books instead of the basic digital book version. In a qualitative study with a struggling reader, McClanahan, Williams, Kennedy, and Tate (2012) explored the experiences of a struggling reader with the story book applications on the iPad. The results of the study showed that the student made a one year's progress in reading within six weeks with the use of interactive applications on the iPad. The findings also suggested that these applications helped the student to focus attention, increased his metacognitive skills in reading, and enabled him to be more confident and to gain a sense of being in control of his learning. 


\section{METHODS}

In this study I made use of a qualitative research design so that I might obtain a deeper understanding of the experiences of struggling readers within tutoring sessions that made use of interactive digital books. I used case study as the major qualitative design of this inquiry. I incorporated Creswell's definition of case study as he defined it in broad terms as a methodology, a type of design in qualitative research, and an object of study, as well as a product of the inquiry. Case study "involves the study of an issue explored through one or more cases within a bounded system (i.e., a setting, a context)" (Creswell, 2007, p. 73). Each of the participants selected for this study served as a single case in this multiple case study. The purpose of this case study was not to generalize inquiry findings, but to learn from them and to open up possible new territory for further research.

\subsection{Research Questions}

My research is centered around two central research questions and two sub-questions:

1. How do struggling readers describe their literacy experiences related to the use of interactive digital books during tutoring sessions?

2. What is the academic potential of using interactive digital books among struggling readers?

2.a. How does using interactive digital books support the reading comprehension of struggling readers?

2.b. How does using interactive digital books support the reading motivation of struggling readers?

\subsection{Context}

This inquiry was located in an elementary level charter school in the Midwest region of the United States. The research school had approximately 80 students from diverse backgrounds $(85.2 \%$ African American and a small percent of White and Latino/a, which was not indicated because the percent was suppressed due to a potential small sample size), who were enrolled in kindergarten through fifth grade programs. 93\% of the students in this school participated in the free or reduced-price lunch program in 2014 (Missouri Department of Elementary and Secondary Education, 2014).

\subsection{Participants}

The students who get "Below Basic" and "Basic" level scores in the content area of English Language Arts in the Missouri Assessment Program (MAP) are targeted as needing reading assistance. According to 2015 MAP results, $53.3 \%$ of the third graders in this school are at the "Below Basic" level, while $20.0 \%$ of them are at the "Basic" level (Missouri Department of Elementary and Secondary Education, 2014). Thus, $73.3 \%$ of the third graders in this school were the potential pool of participants to be recruited for this study.

Six $3^{\text {rd }}$ grade struggling readers were recruited as participants for this study in the elementary school described above. I used purposeful sampling to select the participants for this study. Of the purposeful sampling strategies, snowball sampling followed by criterion sampling was used to select the participants. I selected the school and the participants with the help of a "gatekeeper"- one of my professors, who knows the principal of the school as a snowball sampling strategy. Then I used criterion sampling to select the participants that meet the criteria for this study.

\subsection{Data Collection}

I collected data through the participant observation of tutoring sessions, two semi-structured interviews, document collection, and the use of a field note journal to triangulate my data. I worked one-on-one with each participant for two half an hour sessions each week for a total of two months. In total, I collected data based on 16 individual half an hour sessions with 6 participants. During tutoring sessions, I used level-appropriate interactive digital book applications on iPads, drawing from available downloads from the iPad, App Store. I used my own tablet and purchased the book applications myself. I audio-recorded tutoring sessions with my participants while using interactive digital books. I wrote technical and reflective field notes after each tutoring session. These field notes consisted of descriptions of what was being experienced, such as what social interactions occurred and what activities took place during observation, and of my feelings; insights; interpretations; and reactions to what was observed.

\subsection{Data Analysis}

In this qualitative case study, I used thematic analysis to analyze and interpret the data to identify core meanings. To analyze the data, I used a generic coding process of thematic analysis. The 
generic process involved the following steps: organizing and preparing the data; reading through all the data; beginning detailed analysis with a coding process; using the coding process to develop a description of the people as well as themes for analysis; explaining how the themes have been represented; and interpreting the data (Creswell, 2003). As the first step in the generic process, I accumulated the field note entries, transcriptions of interviews, and documents collected for each participant as raw data. Then, I read through the data to have a general sense of the information. Next, I began detailed analysis by reading through the data and assigning descriptive codes that are aligned with my research questions, when applicable. After I analyzed all the raw data manually, I entered all the descriptive codes to the excel document on the computer respectively for each participant. Then I defined each descriptive code according to its meaning in this study. After analyzing the descriptive codes, I grouped them under the interpretive codes going along with the descriptive codes for each participant. Finally, I grouped the interpretive codes into larger themes that embrace those codes for each individual.

\section{FINDINGS}

The three themes of 'motivation' 'barriers' and 'technology' emerged from the data sources of participants' documents, interviews, and observations.

\subsection{Barriers}

For this study, the theme "Barriers" was described as the participants' challenges preventing them to process and respond to comprehension of text. This theme was detailed further through two interpretive codes of student related barriers and environment related barriers. The interpretive code of student related barriers addressed difficulties in comprehension of text resulting from participants themselves. A theme that was clear throughout my interactions with Marco was "Barriers". Marco had student related difficulties especially in the area of concentration. In the reflective field notes for the first meeting with Marco, I noted: "He is distracted by anything. That seems to be why he cannot fully concentrate on the book or the activities. Marco did not follow the words when the book was reading to him" (Field notes, March 29, 2016). Concentration might be one of the possible reasons for Marco to struggle with reading and processing texts. Marco's concentration went hand in hand with the interpretive code of environment related barriers. The interpretive code of environment related barriers involved difficulties in comprehension of text resulting from participant's environment. In the room, Marco usually wanted to play with the games around the room or in the tablet instead of focusing on the digital text. Dorothy also displayed experiences that were directly related to the interpretive code of environment related barriers. Dorothy had an unfortunate car accident in which she had a stroke. During tutoring, Dorothy mentioned that doctors told her the stroke might be directly related to her strong imagination. Dorothy always talked about extra ideas that were not even related to what was mentioned in the actual story. Another environment related barrier to keep Dorothy struggle in reading was the attitude of her peers. Dorothy sometimes was in a bad mood when I went to pick her up from her classroom. The problem always had to do with her classmates, who poked fun of her, or sometimes the teacher, who she believed did not understand her.

\subsection{Motivation}

The theme of "Motivation" was considered as a source for reaching at an individual's target, value, or belief. This theme centered around three interpretive codes of motivation to learn, motivation to read, and reinforcement. Throughout the tutoring sessions, Alice displayed experiences that were relevant to the interpretive code of motivation to learn and motivation to read. The interpretive code of motivation to learn was evident throughout Alice's data, especially from field notes. Alice was a shy and quiet student. In the first interview, though, I was able to learn that Alice loved Princess Tiana from the animated movie, "The Princess and the Frog." I prepared a folder for each participant to put their tutoring session documents. For Alice, I took a print of Princess Tiana's picture and wrote Princess Alice on a paper in her favorite color below the picture. The next time we met, I showed her the folder, and her eyes widened with surprise and delight. This helped to grab her interest and motivate her to learn and engage in reading more. The interpretive code of motivation to read showed itself beginning with an event that took place during the third time I went to pick up Alice from her classroom. During the first two sessions, Alice did not show much interest in working with me. However, during the third session, things changed dramatically. That day, I went to her classroom to pick Marco to work with. Although Alice knew it was not her turn yet, she grabbed my arm to show me something. Her excitement was clear from her eyes as well as voice. She explained that she went to the library to check 
some books out to read and found the print version of the book, "Acoustic Rooster," which we worked on as her first interactive digital book during our second session together. After that occasion, she showed more interest in the sessions and engaged in the interactive digital books to a greater degree than she had previously done. Beatrice's data. Beatrice was aware of the challenges that had brought her to the tutoring sessions. In one of the tutoring sessions, she openly explained one of her reading challenges: "Some words are not easy. Because words kind of sound like 'o' ' $u$ ' ' $d$ ', but when you write, it is different" (Audio record B., March 31, 2016). The arbitrariness between the sound and how it was written was a big challenge for Madeline to overcome. That is why she kept asking for how a word was sounded out whenever she was not sure how to pronounce it. Sometimes, she just stopped reading when there was a big word for her. At such times, she looked at me without saying anything. Her look had a big echo of 'help me out!' In spite of her awareness of such challenges, Beatrice was very motivated to read. She especially wanted to read high-level books like her mother reads. Beatrice was the only participant that kept asking for the meaning of unknown words. She seemed to want to learn and to read. Actually, she had the interest, curiosity, and motivation to read; however, they did not help her to accurately pronounce the words, understand the text, process it efficiently, or respond to the text in a manner to show comprehension. Beatrice had interest in reading that brings fun to her. When that was not the case, she lost her motivation and desire to read. In a conversation, she explained how she loved to work one-on-one together in that small room. She stated: "Reading is not fun in the class, but in here, with like nobody else in here, but you and I. It feels like we have more and not crowded. I like it better here" (Audio record, April 6, 2016).

\subsection{Technology}

The theme of "Technology" addressed the use of digital tools to improve participants" literacy skills. This theme was further sorted into two interpretive codes of interactive technology and technology fondness. "Technology" was a theme that appeared most frequently across all data sources of Marco. Marco displayed experiences mostly related to the interpretive codes of interactive technology and technology fondness. The interpretive code of interactive technology addressed a wide range of components from the use of hotspots to their being a source of distraction. Marco constantly wanted to touch hotpots without worrying about understanding the text. He kept pressing on the hotspot before, after, and even during reading the text on a page. "Technology" was a prominent theme in the field notes from the observations of tutoring sessions with Heidi. Heidi had positive attitudes towards the use of digital books with interactive features just like the hotspots used for the purpose of this study. During the second interview, Heidi explained her positive attitude towards working with interactive digital books with read to me feature by stating: "I think they were helpful. I need to know what the character is saying from their own mouth, like not from the words, from their own mouths. When they make noise, that makes me happy. We never did that before" (Second Interview, May 5, 2016). At the beginning, Heidi told me that she was surprised to hear that the book can read to her. She thought the person dubbing the story was the same character as in the story related to the content and picture. She thought it is a necessity to listen the story from the characters' own mouths, which she stated made her happier. Data from Beatrice also centered on the interpretive code of interactive technology. During our initial conversations about what Beatrice thinks of using technology to read, she explained that she loved to use technology for anything. Her first reaction towards the first hotspot she moved was: "It is like a movie!" (Field notes, March 23, 2016). After a couple more sessions, I asked her what she thinks of using interactive digital books with hotspots, she answered: "They were fun and really like awesome. Because you know how the books you read, you use your imagination and can see in your mind. I love that" (Audio record B., April 7, 2016). She further stated: "You feel like you can go inside of the book to explore. Your brain pops out like fun parties" (Audio record B., April 7, 2016). Data from Madeline also focused on the interpretive code of interactive technology. At the beginning, after she pressed on a couple of hotspots, she said: "This is like a movie, but in a book" (Field notes, March 25, 2016). This is a short statement, but a powerful one. She related interactive digital books to movies, and she had fun while using them. The statement indicated that she found the interactive digital books with hotspots as live as movies. Madeline also emphasized that such books might bring out imagination by explaining: "It was pretty interesting. Because when you read it, imagination comes in your mind like imagine like princesses wandering around" (Second Interview, May 5, 2016). When she was specifically talking about what hotpots mean to her, she stated: "They are helpful, because they go to the story and when you press on it, it makes you feel that you can like turn the page and do another one and another one" 
(Second Interview, May 5, 2016). The interactive feature of such books reminds Madeline of how fun a book might be. She wishes the books to move. No matter how funny or boring the story of a text is, it seemed that Madeline expected more action from a book.

The interpretive code of technology fondness explained the devotion of students towards the use of digital tools for fun. Marco was fond of any type of technology. At the first session with him, I mentioned how we were going to use tablets to read and improve his literacy skills. Marco was thrilled at the idea of using tablets regardless of what purpose we were going to use it. He explained his love of technology by saying: "Yeah. iPaaaaaads! I love to play games with the computer" (Audio record M., March 22, 2016). Throughout the tutoring sessions, Marco's eyes widened after touching a hotspot. The first time he touched a hotspot, he stated: "Wowww! Did you see that? I will do that again. You touch it" (Audio record M., March 22, 2016). When there was a hotspot he really loved, he asked me to touch it, too. In addition, the interpretive code of technology limitation revealed itself in Heidi's data. The interactive digital books used for this study had some of limitations, such as small fonts and distracting stars lighting around hotspots at the time of reading. Also, there was no way to de-activate the 'read to me' feature or to turn off the voice. Thus, it worked non-stop until everything on the page was read. Every time Heidi turned a page, the letters were big enough to be easily read. However, turning a page was connected to the 'read to me' feature, so after the 'read to me' feature was done reading, no matter whether the sound was on or off, it made the sentences smaller which made it, sometimes, hard to see. In such cases, Heidi stated: "It drives me crazy when it gets that small" (Audio record H., March 25, 2016).

\section{DISCUSSION AND CONCLUSION}

In an effort to derive meaning from my participants' experiences and to highlight some of the study implications, I included the voices of the respondents above. In this way, I examined their experiences and uncovered various narrative themes within and across their experiences. I consider here how their storied experiences and the related narrative themes were highly useful for shedding light on some of the outcomes of using interactive digital books with struggling readers.

In this study, I worked individually with each struggling reader student participant. Working one-on-one was beneficial to struggling readers in this study as supported by the literature. It might also be of special interest to teachers and parents in assisting struggling readers to improve their reading proficiency. In addition, the findings might open new doors for teaching and learning opportunities that are not available in traditional print books. This study might also enable some teachers to develop a literacy curriculum adaptable with the individual needs of some of the struggling readers.

There are a couple of issues to consider before deciding to implement this technology in the process of learning and practicing. This technology demands costs and training from teachers and time to guide students. Keeping all these in mind, this technology might seem like burden more than benefit. Although this study focuses on the use of interactive digital books to support the literacy practices of struggling readers, this technology should not be understood as a substitute for teaching. Technology might be a tool to support instruction, but not the target of it. Therefore, interactive digital books should be considered as an augment to support some of the literacy practices if needed and used by a teacher or parent appropriately.

In the $21^{\text {st }}$ century, it is crucial to prepare students for both print-based and technology-based sources to support their learning. Teachers might benefit struggling students through the integration of sources like technology that is adaptable with their individual needs. However, unless effective digital tools that are appropriate to students are chosen and used, technology might have some negative effects on the education of students. Selfe (1999) suggested that technology might be integrated into curriculum effectively only if the dangers of it are known and taken action upon. Teachers might benefit their students if they choose effective and quality digital tools, know the negative effects of the target technology, and integrate it considering those negative effects and finding innovative ways to refrain from them. Not only teachers but also parents might benefit from the integration of interactive digital books into their children's education when they use it meaningfully. Parent involvement in children's education has shown to result in better academic outcomes, fewer behavioral problems, and lower high school dropout rates (Henderson \& Berla, 1994). Parents, especially those who need assistance in the education of their children outside the school, might benefit from the vast amount of beneficial sources that technology provides. Some interactive digital books have vocabulary help built in them; most of them have 'read to me' feature; some of them highlight the words when 'read to me' feature is activated 
for easy tracking; and some of them have comprehension questions and answers at the end of texts. Parents might benefit from such sources of interactive digital books to help out their children, especially during times when they feel insufficient because of a learning barrier, not having enough formal education, being from another culture and unfamiliar with the vocabulary, structure, or pronunciation of target language. Children might use these sources without necessarily having somebody around them. However, children are not always aware of the negative sides of technology (Udo, 2001). Unless they have some guidance from a parent or teacher who is aware of the negative sides and take action upon them, they might easily get distracted. Thus, it might be of significance to have a parent or teacher as a facilitator to support literacy instruction while using interactive digital books.

This study has some implications not only for educators and parents but also for digital text designers. The design world is a profit-based world, so designers put the attraction side of products upfront in order to earn more money. They believe that is how they grab more attention of more customers (Cooper, 2004). The designers put the fun aspect upfront by making the content inferior to layout of the product. By doing so, they may not consider the benefit of their products to their customers. During the course of this study, I struggled with text selection. In particular, I noticed that when the word of digital books is entered in the search box of app store on a tablet, there is a vast majority of sources. Using the search term of interactive digital books seemingly results in a drop in the pedagogical quality of the books. As well, a majority of interactive digital books are the interactive versions of classical books that target for elementary level children. When these books are analyzed, it is unfortunate to see that the interactivity in these books is just intended to be a source of amusement that is unrelated to the content of the text. In the process of looking for interactive digital books, I had difficulty in finding books that would best serve the needs of struggling readers in terms of contributing to their motivation to read by engaging with the text virtually. It was even more challenging to locate books that also aimed to improve the literacy ability of struggling readers through quality resources that are organized by grade level and that include content- related interactivity. After a long process of searching, I was able to find suitable texts for my participants. However, even the books that I selected had some limitations, such as having small fonts when the "Read to Me" feature is inactive, including some hotspots that were indirectly related to the content of the text, and adding distracting stars that lit up around hotspots at the time of reading. For this reason, I recommend that digital text designers may focus more on the importance of content and how it is conveyed with the additional features that they provide in interactive digital books, such as hotspots, read to me, games, and puzzles.

At the same time, following the results of this study, I assert that technology can be used meaningfully and effectively to support learning and teaching. If educators want to integrate technology in their classrooms, they do need to consider the strengths and weaknesses of the technology that is chosen in relation to increasing student academic achievement. Another point that teachers might consider is whether interactive digital books or similar technologies can be detrimental to student learning, even if they are included for educational purposes. In this study, hotspots became a source of distraction at the beginning when students were left alone to discover how to use interactive digital books. However, they became a source of motivation with appropriate guidance at further reading processes of these digital books. If teachers know in what ways the selected tool can help them to achieve better learning outcomes, and if they know how their students approach this tool, then there is a high possibility of minimizing the limitations and maximizing its positive impact on learning processes.

Additionally, technology can be a great tool to differentiate instruction, so it might be used effectively to address individual needs of learners. For example, my participants, Marco, Dorothy, Heidi, Alice, Beatrice, and Madeline, all had struggles with reading and writing, as observed in the classroom and by their test results. The use of interactive digital books proved to be one effective means for working with their individual needs in reading, and so they are a recommendation of this study as long as guided text selection and instructor oversight is available. Technology such as these digital books might also help struggling readers when their instructional path is integrated appropriately, as it helps other groups of learners who need a personalized and differentiated instruction. Thus, technology might take on a specific role to minimize the achievement gap between struggling readers and their peers.

As the outgrowths of my study, this study might further have implications for the education of second language learners. The multimodal features in the digital books might be used to support not only struggling readers but also second language learners in terms of having built in dictionaries to 
check for the meaning of unknown words. Second language learners might also benefit from hotspots when they are designed related to the content of the text. The multimodal features in digital books might also be constructive for second language learners because they have chance to hear the text from a native with the 'read-to-me' feature. All in all, these additional tools in digital books might enable second language learners to support their language learning process effectively when they are used conscious of their positive and negative features. Furthermore, vocabulary knowledge of second language learners might be boosted through systematic vocabulary activities in digital books. More specifically, hotspots might be designed to teach specific vocabulary with the inclusion of more actionbased-hotspots relevant to the target vocabulary throughout the texts of interactive digital books. For example, characters might hug each other when the user clicks on the target word of 'hug.' Visual aids through the actions of characters or objects of the text might benefit vocabulary learning and storage of individuals. Demiroz and Demiroz (2018) supported this phenomenon and claimed that language learning is more efficient when cognition is supported with kinesthetic activities.

Social justice is another important issue to consider in the implementation of these interactive digital books. Social justice is usually defined as providing an equitable education for all so that individuals become change agents and fight for what believe is right. I remember seeing a caricature, in which there are 3 individuals with different lengths trying to look over a bench to watch a baseball game. In the caricature, there are two pictures with two different scenarios to describe the difference of equity and justice. In the first picture of the caricature, equity is described as giving the same-lengthbanks so that they can see the game. However, the short individual could not still watch the game because the bank is not long enough for his length. In the other picture of the same caricature, justice is described as giving banks as long as each individual needs so that they can really see the game. As it is identified in this example, there is a slight, but very significant difference between equity and justice. If each student is supported with the tools appropriate to their needs, social justice might be achieved. In this case, using sources like interactive digital books to appeal to the needs of struggling readers means providing social justice. However, we also need to take into consideration other issues of access to such sources. Access to technology and Internet is difficult especially for students from economically disadvantaged backgrounds. In such cases, technology becomes a source of providing social injustice for students of low-income-families. Fortunately, the participants I worked with had access to technology in the school because of a grant that the school received to purchase tablets and use them as support for students' learning. They also had access to technology outside of school with either smart phones or tablets that their parents had. However, not every student has access to technology to support learning. Thus, the use of technology should be carefully considered because it might be both a source of social justice and injustice. Access to cultural education is one way of providing social justice. However, not all the books on the market are designed to provide multicultural education for all. The application that I purchased is one of the rare ones that target education aspect more than money. Although this is the case, there are not many multicultural books within the application. There are a couple of books designed to reflect the culture of African Americans, of which my participants, most of whom were African Americans, were delighted to read a text that they felt connected to. Most of the books on the market still do not help students comprehend the racial, ethnic, and gender-related problems they face in their lives. More works of female authors might be published to equalize the number of male and female authors. More stories from various cultures might be shared to have a general idea of the different cultures in the schools and society. The different sides of the stories, especially history stories, might be provided so that readers might look for their own truths to provide students with authentic multicultural education.

In conclusion, reading is one of the amazing skills that most human beings can develop with a level of fluency over time. However, reading cannot be learned and practiced for everyone in the same way. In this study, I wanted to shed some light on the world of struggling readers and to help them overcome their challenges with the use of interactive digital books. If students cannot read, it is not their fault. Instead, the opportunity and responsibility is on the shoulders of educators to support students so that they can interact with text in meaningful ways. It is my hope that this dissertation becomes a voice for ay struggling reader and widens teachers' avenues so that they can broaden their students' lives by the joys of engaging in reading. My intention is to inspire, especially educators, to find new and exciting ways to support and inspire their students. 


\section{REFERENCES}

Allington, R. L. (2007). Intervention all day long: New hope for struggling readers. Voices from the Middle, 14(4), 7-14.

Anderson-Inman, L., \& Horney, M. A. (2007). Supported e-texts: Assistive technology through text transformations. Reading Research Quarterly, 42(1), 153-160.

Boone, R., \& Higgins, K. (2007). The role of instructional design in assistive technology research and development. Reading Research Quarterly, 42(1), 134-153.

Cheung, A., \& Slavin, R. E. (2013). Effects of educational technology applications on reading outcomes for struggling readers: A best-evidence synthesis. Reading Research Quarterly, 48(3), 2772999.

Chiong, C., Ree, J., Takeuchi, L., \& Erickson, I. (2012). Print books vs. e-books. Retrieved from http://www.joanganzcooneycenter.org/wpcontent/uploads/2012/07/jgcc_ebooks_quickreport.pdf

Cooper, A. (2004). The inmates are running the asylum: Why high-tech products drive us crazy and how to restore the sanity. Indianapolis, IN: Sams.

Creswell, J. W. (2003). Research design: Qualitative, quantitative, and mixed methods approaches. Thousand Oaks, CA: Sage.

Creswell, J. W. (2007). Qualitative inquiry and research design: Choosing among five traditions. Thousand Oaks, CA: Sage.

Dalton, B. (2014). DIY e-books: Designing enhanced texts. The Reading Teacher, 67(7), 543-546.

Demiroz, E., \& Demiroz, E. (2018). Enactive nature of scholarship and e2TPR. In Wang, V. C. (Ed.), Handbook of Research on Positive Scholarship for Global K-20 Education (pp. 201-216). IGI Global.

Falth, L., Gustafson, S., Tjus, T., Heimann, M., \& Svensson, I. (2013). Computer-assisted interventions targeting reading skills of children with reading disabilities: A longitudinal study. Dyslexia, 19(1), 37-53.

Gibson Jr, L., Cartledge, G., \& Keyes, S. E. (2011). A preliminary investigation of supplemental computer-assisted reading instruction on the oral reading fluency and comprehension of firstgrade African American urban students. Journal of Behavioral Education, 20(4), 260-282.

Guthrie, J. T., \& Davis, M. H. (2003). Motivating struggling readers in middle school through an engagement model of classroom practice. Reading \&Writing Quarterly, 19(1), 59-85.

Henderson, A. T., \& Berla, N. (1994). A new generation of evidence: The family is critical to student achievement. Washington, DC: Center for Law and Education.

Kena, G., Aud, S., Johnson, F., Wang, X., Zhang, J., Rathbun, A., Wilkinson-Flicker, S., \& Kristapovich, P. (2014). The condition of education 2014 (NCES 2014-083). Washington, DC: U.S. Department of Education, National Center for Education Statistics. Retrieved September 21, 2015 from http://nces.ed.gov/pubsearch

Laverick, D. (2014). Supporting striving readers through technology-based instruction. Reading Improvement, 51(1), 11-19.

McClanahan, B., Williams, K., Kennedy, E., \& Tate, S. (2012). A breakthrough for Josh: How to use of an iPad facilitated reading improvement. TechTrends, 56(3), 20-28.

Missouri Department of Elementary and Secondary Education. (2014). District and school information. Retrieved from http://mcds.dese.mo.gov/Pages/District-and- School-Information.aspx

Selfe, C. L. (1999). Technology and literacy: A story about the perils of not paying attention. College composition and communication, 50(3), 411-436.

Slavin, R. E., Lake, C., Davis, S., \& Madden, N. A. (2011). Effective programs for struggling readers: A best-evidence synthesis. Educational Research Review, 6, 1, 1-26.

Udo, G. J. (2001). Privacy and security concerns as major barriers for e-commerce: A survey study. Information Management \& Computer Security, 9(4), 165-174.

Wasik, B. A., \& Slavin, R. E. (1993). Preventing early reading failure with one-to-one tutoring: A review of five programs. Reading Research Quarterly, 28(2), 178- 200.

Zucker, T. A., Moody, A. K., \& McKenna, M. C. (2009). The effects of electronic bookson prekindergarten-to-grade 5 students' literacy and language outcomes: A research synthesis. Journal of Educational Computing Research, 40(1), 47-87. 